Article

\title{
Signs of the United Nations SDGs in University Curriculum: The Case of the University of Iceland
}

\author{
Auður Pálsdóttir ${ }^{1, *}$ and Lára Jóhannsdóttir ${ }^{2}$ (i) \\ 1 Department of Subject Teacher Education, School of Education, University of Iceland, Stakkahlíð, \\ IS105 Reykjavík, Iceland \\ 2 Environment and Natural Resources, Faculty of Business Administration, University of Iceland, \\ Gimli v/Sæmundargötu, IS102 Reykjavík, Iceland; laraj@hi.is \\ * Correspondence: audurp@hi.is; Tel.: +354-525-5332
}

check for

updates

Citation: Pálsdóttir, A.;

Jóhannsdóttir, L. Signs of the United

Nations SDGs in University

Curriculum: The Case of the

University of Iceland. Sustainability

2021, 13, 8958. https://doi.org/

$10.3390 /$ su13168958

Academic Editors:

Fermín Sánchez-Carracedo, Jordi Segalàs Coral and Gemma Tejedor

Received: 5 July 2021

Accepted: 5 August 2021

Published: 10 August 2021

Publisher's Note: MDPI stays neutral with regard to jurisdictional claims in published maps and institutional affiliations.

Copyright: (c) 2021 by the authors. Licensee MDPI, Basel, Switzerland. This article is an open access article distributed under the terms and conditions of the Creative Commons Attribution (CC BY) license (https:/ / creativecommons.org/licenses/by/ $4.0 /)$.

\begin{abstract}
Sustainability is a pressing topic in all universities. Institutions are determining what the implications of such a development are, e.g., on how courses that students are provided with should develop, what to change, what to add, and how these changes could be brought about. The purpose of this research was to provide an overview of the United Nations Sustainable Development Goals (SDGs) in the curriculum of five schools at the University of Iceland and an overview of individual SDGs for the university, to identify the main challenges and opportunities for improvement. Data collection included analysis of every single university's course description and learning outcomes using a curriculum analysis key designed for the SDGs. Results indicated strong signs of SDG 4 (quality education) at the School of Education and the School of Social Sciences and SDG 3 (good health and well-being) at the School of Health Sciences. For the university, the results revealed a very limited emphasis on four SDGs, i.e., SDG 1 (no poverty), SDG 2 (zero hunger), SDG 6 (clean water and sanitation), and SDG 13 (climate actions). The results can serve as a benchmark for other universities, e.g., for comparison of results and their situation when creating policy and practices that include implementing the SDGs. Additionally, they can be used for comparison within the University of Iceland as a whole or within each school to monitor change.
\end{abstract}

Keywords: sustainable development goals; curriculum; university; higher education; strategy

\section{Introduction}

Extensive research indicates that human behaviour on the planet is characterised by unsustainability [1]. People's ideas about "the good life" have led to consumption that exceeds what the planet can sustain. Thus, the task facing humanity is to change the way people think and behave if the limits of nature are to be respected [2]. This means that sustainable development and sustainability does not only concern the environment but also social justice, health and well-being, culture, and the economic life of societies. To tackle these challenges collectively on a global scale, the United Nations defined Sustainable Development Goals (SDGs). Consequently, the integration of sustainable development, and the SDGs, has become a relevant topic in Higher Education Institutions (HEIs) that are increasingly attempting to take responsibility as agents in its promotion [3].

\subsection{The Role of the SDGs within Universities}

The SDGs were adopted in 2015 by all United Nations Member States and include 17 goals associated with 169 targets and 232 indicators [4,5]. The goals provide a holistic approach that together contribute to and evaluate the sustainable development of each community and country. The main aspects of the SDGs can be synthesised under five cross-cutting themes, which are people, planet, prosperity, peace, and partnership [6], also emphasising that no individuals or groups should be left out [4,5]. Implementation of the 
goals therefore requires cooperation of various stakeholders, including the government, the private sector, civil society, and the academic community $[4,5]$.

The task for societies is to solve complex challenges. These are more urgent than ever, and the prospects of meeting policy objectives, such as reducing greenhouse gas emissions, protecting ecosystems, preventing famine, and strengthening food security, are largely not on track $[1,7,8]$. In this context, is it worth highlighting that the role of universities in preparing people for jobs in knowledge societies requires the skills and capacity to deal with poverty and injustice and the decline of the natural environment [9]. A growing systemic problem that appears, e.g., in climate change and epidemics such as COVID-19 [10], requires extensive cooperation across different levels of society because such problems involve risks on larger scales than generally examined [11].

The role of universities has been significant in the development of society. Their role is not only to be important sources of many of the new ideas in science and technology that contribute to innovation, but also, they have a prominent role in shaping society [12]. In law on Icelandic universities (no. 63/2006) it is stated that universities' role is to advance both the creation and dissemination of knowledge and skills, to both students and society in general. By this, all work within universities is supposed to strengthen society's infrastructure and its international relations [13]. This means that the leadership role of universities is clear in preparing young people to face modern challenges.

Within the context of universities, the above understanding is emphasised. The concept of sustainability is viewed as "a normative principle that can be described as a benchmark of global and intergenerational justice in the face of challenges currently posed by an earth system in transformation. Ethically and politically, sustainable development is not a pre-determined goal that is imposed by some external entity, but rather an openended search process with heterogeneous target components, which therefore makes it pluralistic and culturally variable. Its focus is long-term responsibility to ensure ecological sustainability, social justice, and economic performance. Its aim is to strengthen the skills required to take an active part in social life" [14] (p. 16). How then, does a university transform itself towards sustainability and the SDGs?

The purpose of this research was, therefore, to provide an overview of the United Nations Sustainable Development Goals (SDGs) in the curriculum of the five schools at the University of Iceland and an overview of individual SDGs for the university, to identify the main challenges and opportunities for improvement.

\subsection{Embedding the SDGs within Higher Education Institutions}

Today, sustainability is a pressing topic in all Higher Education Institutions (HEIs) [15] that are determining what the implications of such a development are for instance, on how courses that students are provided with should develop, what to change, what to add, and how these changes can be brought about. However, embedding sustainability in the curriculum is proving to be a challenging task, particularly for education for sustainability to cut across the whole course of study and the whole institution. Research on SDGs' implementation in HEIs shows, for example, that there is a need for examining how universities are progressing towards integration of competences for sustainable development in the education programmes, with curricula assessment being an important step providing a picture of where the courses are addressing sustainability issues and where they can be improved [15].

The United Nations (UN) does not publish guidelines on what universities should do or how. However, five common themes have been identified in academic publications on higher education (HE) and sustainable development. These themes are sustainability in general, teaching issues, research issues, greening of campuses, and other unspecified topics [16]. More recently, the focus has been on implementation strategies emphasising how to embed the SDGs within HEIs [16,17]. 


\subsection{Implementing the SDGs in Universities}

It seems that the implementation of the SDGs is in its infancy in most universities and more systematic efforts are needed for aligning universities' core operations with the SDGs. However, in one study, results indicated that $92 \%$ of 167 participants in 17 countries spread over five continents agreed that the SDGs should be a part of the university's core curriculum [17].

To support universities in implementing the SDGs, the UN Sustainable Development Solutions Network has published guidelines for universities together with examples that can be kept in mind when forming a policy on ESD in each university [10]. In these guidelines it is emphasised that the most important step for universities is to tailor all teaching practice and research towards the SDGs for students to achieve the necessary knowledge, skills, and attitudes to advance sustainable development.

On the basis of research and the experience of implementation of the SDGs, a five-step model was defined for effectively creating policy and practices of universities [18] and has been organised in three phases [10,19] (see Figure 1).

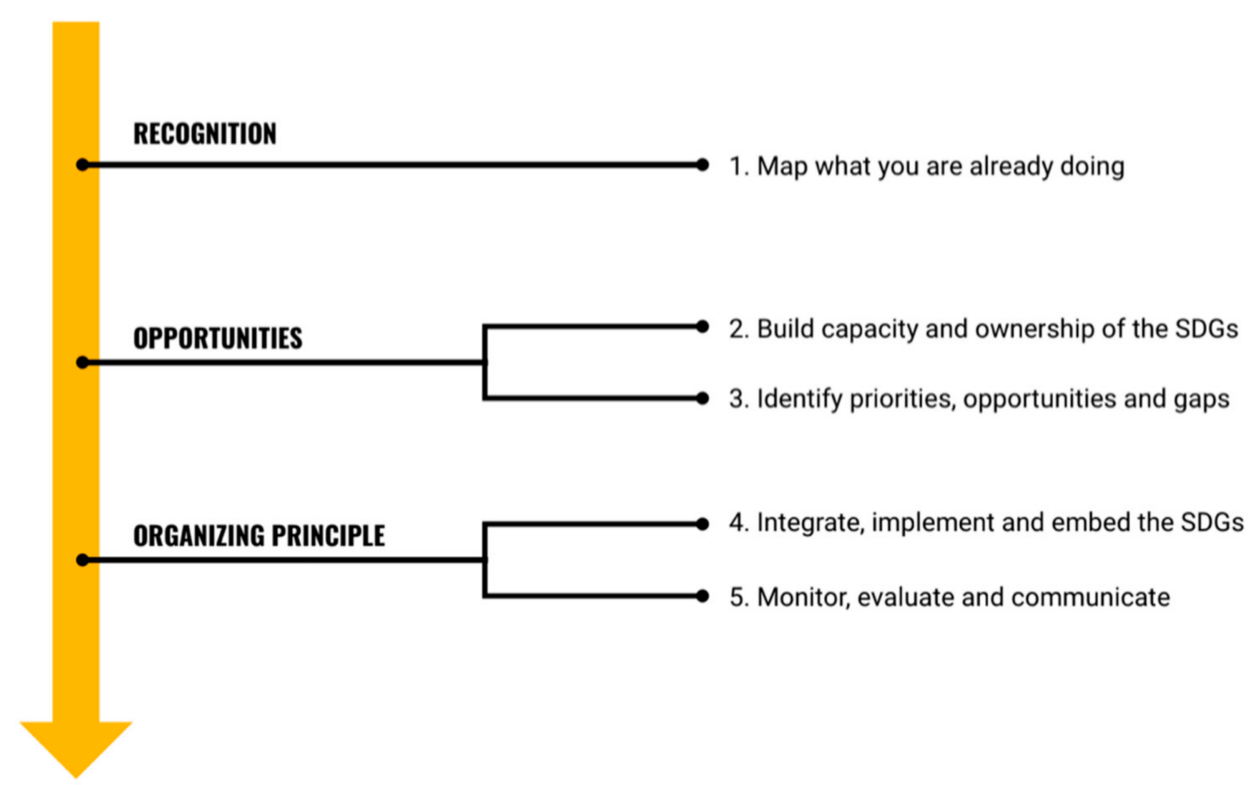

Figure 1. Overview of the step-by-step SDG integration process [19] (p.26).

The first phase is Recognition, which includes a focus on identifying and acknowledging what a university is already doing to contribute to the SDGs. This can provide a powerful narrative about impact and a strong impetus for further action. The second phase identifies Opportunities. Here, different areas across the university recognise the usefulness and importance of the SDG framework and find opportunities to use it to frame or drive discrete activities and programs without an overall strategy. The third phase includes establishing an Organising principle. The ongoing and far-reaching impact will come if the SDGs becomes part of "business-as-usual" for the university, by recognising and integrating the SDG framework into all relevant university governance structures and frameworks [19].

The challenges universities face is considerable when implementing sustainability and the SDGs in their policy, curricula, and daily practice. Some universities have analysed the situation within their own institutions, but extensive comparison of how things are carried out is unclear. Some attempts have been made to map how the SDGs appear in universities' curriculum, research, and policies. In the University of Helsinki, the university's emphasis on new research, teaching, and administration and operations were assessed with regard to the SDGs [20]. Several types of administrative documents were analysed, as well as information on research and applications for grants, descriptions of programmes for 
bachelor's and master's students, and annual reports. Research revealed a clear emphasis on SDG 4 (quality education) in all analysed documents. Additionally, four SDGs appeared in addition in research, i.e., SDG 8 (decent work and economic growth), SDG 9 (industry, innovation, and infrastructure), SDG 17 (partnerships for the goals), and SDG 3 (good health and well-being), but these were identified in the documents rather than being the subject of the research itself. However, little emphasis was found on SDG 1 (no poverty), SDG 2 (zero hunger), SDG 5 (gender equality), and SDG 6 (clean water and sanitation) in analysed documents on research. Analysis of programmes revealed a clear emphasis on SDG 3 (good health and well-being) but nearly none on SDG 1 (zero poverty). On the other hand, fairly strong emphasis was provided to SDG 17 (partnerships for the goals) and SDG 4 (quality education). Signs of SDG 5 (gender equality) were nowhere found in this research.

In a study conducted at the International University of Catalonia, the aim was to explore the principles linked between the SDGs and the learning and teaching practices in sustainability [21]. Several visions, difficulties, and challenges were identified in this mixed-method study around the concept of sustainability, which collectively allowed the authors to describe and portray a specific starting position in relation to the SDGs at the International University of Catalonia. Here, the SDGs were categorised into the three dimensions of sustainability (socio-cultural, environmental, and economical) whether the used approaches were holistic or not. The universities' reports and interviews with university staff were analysed by looking for SDGs keywords. Then, a SWOT-analysis was carried out on the interview data. The findings indicated a clear emphasis on health, but other emphases appeared less and more distributed. For example, some indications were on natural resources, human rights, and gender issues, but less or no emphasis was found on climate change, regional development, actions on poverty, or corporate social responsibility. Interviews also revealed an emphasis on the importance of ESD for the overall university and the importance of an interdisciplinary approach within the curriculum.

In the University of Seville in Spain, a study was conducted to analyse the presence of sustainability in terms of curriculum content and training in competence for students, teachers, and the curricula of Science of Education degree courses at the university. Two questionnaires were used, and four reflection groups, in which a total of 49 teachers and 170 students participated, were formed. The results revealed that there seems to be a low presence of sustainability in Science of Education degree courses, but the students expressed a high degree of interest in receiving sustainability training [22].

At Harvard University, a study was conducted on how universities approach implementation of the SDGs. The aim was to explore different ways of strategizing sustainability toward delivering the SDGs in a university setting with three examples from Englishspeaking universities: Plymouth in the UK, the American University in Bulgaria, and Harvard University [23]. The focus was on how implementation of the SDGs was approached and how it progressed. The results of the analysis in these three universities revealed that each case is in effect a "living lab," positioning sustainability as an intentional and aspirational strategy with sustainable development and the SDG framework as a means to that end. Leadership at all levels, and by students, was key to success in acting with a shared purpose, e.g., using the SDGs as an overall framework for the universities' work and as a base for policymaking. Additionally, there were clear signs of the importance of extensive projects within each university counting positively in the progress since such projects required collective efforts [23].

In Bologna University in Italy, all learning opportunities, research, policy, and other university tasks were analysed using four dimensions based on the UN SDGs [24]. The first dimension was training including all courses that could be related to the SDGS, the number of students that could participate in these courses, and all collaborative projects available. The second dimension was on research, which was assessed by publications and citations together with ongoing research projects. The third dimension was the role of the university, concerning research and collaboration projects available for staff and students 
for participation, within their own country and internationally. The fourth dimension was the institution itself, where the focus was on the performance of the university regarding sustainability, e.g., less use of clean water, energy and energy production, plus other measurable components. The results of this work have been published in several reports based on the SDGs, explaining students' and staff's increased knowledge and awareness of the content of the SDGs and the processes required to achieve them. These have then increasingly been used to develop criteria for the university in their work [24].

In a practice-based research project conducted in 15 HEIs in 12 countries, an insight was gained into how sustainability is incorporated in curricula, i.e., which competences are being developed and which pedagogical approaches are being used to develop the competences and how these two relate to each other [15]. The research was based on each course teacher responding to a survey including 40 criteria in six sections; background questions, self-assessment of sustainability criteria taught, pedagogical approaches used, competences covered in the course, types of learning, and open-ended questions about the incorporation of sustainability in courses. The response rate was $9.8 \%$, and thus generalisability was not strong. However, the results provided valuable information on how sustainability competences can be better developed in class and on how to better develop all the sustainability competences as defined in the provided literature [25]. No particular focus seemed to be on if the UN SDGs were present in neither the HEIs curriculum, and thus the policy of the institution, nor if the institutions emphasise the inclusion of the SDGs as part of their policy.

As the above examples reveal, different universities are walking different paths at different paces regarding if and when they include the SDGs in their policy and practice. Some have approached the first phase (recognition) of the guidelines for implementing the SDGs into universities in parallel with the second phase (opportunities) [19] using different methods and different support services within their institutions. In the University of Iceland, little attention has been on to what extent course offerings serve the SDGs and students' learning opportunities. Thus, the purpose of this research was to provide a holistic overview of the United Nations Sustainable Development Goals (SDGs) in the curriculum of the five schools at the University of Iceland and an overview of individual SDGs for the university, to identify the main challenges and opportunities for improvement.

This article is structured as follows. After this introduction, which provided the literature context of the study, comes Section 2 with information on the case in question, i.e., the University of Iceland, and the research approach in the four phases of the research. Section 3 introduces the results in three parts, first for the University of Iceland as a whole, then for each school of the University, and finally for each SDG. Section 4 provides combined discussions and conclusions.

\section{Method}

Section 2 provides information about the case in question, i.e., the University of Iceland and its sustainability emphasis before providing information about the research methods employed.

\subsection{The University of Iceland and Sustainability}

The University of Iceland is a state university, located in the capital city of Reykjavík. Internationally, it is known for progressive research and teaching in over 400 programmes within its five schools: the School of Education (SoEd), the School of Engineering and Natural Sciences (SoEN), the School of Health Sciences (SoHS), the School of Humanities (SoHu), and the School of Social Sciences (SoSS) [26]. The university has for years been ranked among the best universities in the world, or in the 401-500th place in terms of overall ranking, and in 301-400th in terms of impact, according to the THE World University Rankings [27]. The University of Iceland is on a total of 14 lists of the world's leading schools in specific fields of study according to the Shanghai Global Ranking of Academic Subjects for the year 2021 (for instance, ranking number 10 worldwide in remote sens- 
ing) [28]. Other fields are uniquely Icelandic with studies related to the Icelandic Sagas and manuscripts, language, literature, ethnography, folklore, and cultural heritage [29]. Other unique Icelandic data include "complete genealogical data, and climatological, glaciological, seismic, and geothermal records" [26]. In 2019, the number of registered students was around thirteen thousand, and the number of employees, including administrative staff and academics, was almost seventeen hundred [30].

In the present and previous policy of the University of Iceland there has been an emphasis on present time challenges and implementing sustainability into learning and teaching, governance and management, research, and outreach [31-33].

\subsection{Research Methods}

This study was based on an analysis of course descriptions (being 4-6 lines describing the content) and learning outcomes for all courses listed in the course catalogue of the University of Iceland for the 2019-2020 school year. All courses were analysed whether the courses were taught that academic year or not, since many courses are taught every second year. Information about all the courses is accessible on the university website [34], both in Icelandic and English.

The work was approached in four phases. In the first phase, the preparation phase, the project leaders who are the authors of this article created an SDG curriculum analysis key and a data-recording sheet (see Table 1). Then, the authors formed a list of keywords relevant to each of the SDGs using United Nations sources [35,36]. The purpose was to have content-related concepts when looking for signs of each SDG. For instance, for SDG 1 , no poverty, the list included keyworks such as developing countries, extreme poverty, hunger, unemployment, and vulnerability.

Table 1. Data-recording sheet for the research project.

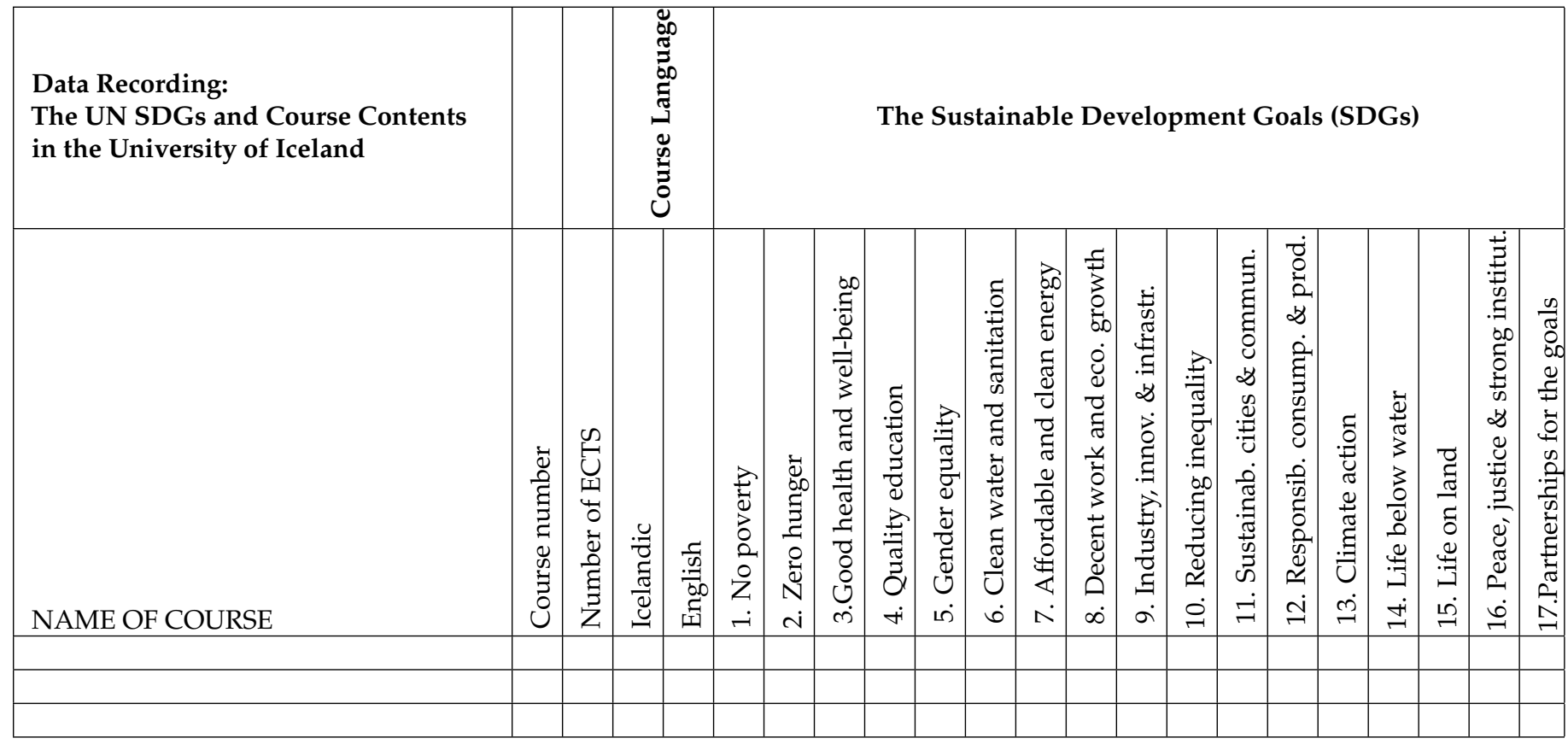

In the second phase, the pilot phase, the aim was to ensure the quality of the data collection. The master's students (selected from a list of applicants) with the project leaders formed a collective working group that met regularly during the 2019-2020 academic year. The purpose was to share information and pilot test the analysis key developed for the research and to compare and discuss the results of the piloting to ensure the quality, reliability, comparability, and consistency of the data collection and analysis to the best possible level. Many perspectives and terms for validating findings of qualitative research 
exist. Wittemore, Chase, and Mandle [37] have, according to Creswell [38], put forward 29 procedures for validating the quality of qualitative work. He (p. 209) suggests that "qualitative researchers engage in at least two of them in any given study." Procedures that were relevant to this research included: triangulation, peer review, and debriefing established through a benchmark between researchers, under supervision of the research leaders, as described above.

The third phase was the execution phase, when all data was collected, which took place in February and March 2020.

In the fourth phase, the final phase, the writing of theses finished, the results were summed up, and collective data was prepared for the presentation and writing of articles.

The variables in this research included, e.g., course language and size in European Credit Transfer and Accumulation System (ECTS) credits. Then, all data was distinguished by the five schools of the university.

An example of how the data was recorded can be seen in Table 1. For example, for each course where evidence of each SDG was found in course descriptions or the learning outcomes, the value 1 was recorded. Thus, each course could get the value 1 only once for each SDG, and each course could get a score for more than one SDG. This approach was used to facilitate descriptive quantitative analysis of the results.

The SDG curriculum analysis key was based on concepts relevant for individual SDGs using the United Nations sources. For example, for SDG 1 (no poverty), the list of keywords (including explanations about these keywords) included e.g., extreme poverty, exposure, minimum living expensive, standard of living, unemployment, and vulnerability [36], and the researchers had these concepts and explanations in mind when the data analysis was executed.

\section{Results}

The results are presented in three sections, first for the University of Iceland as a whole, then for each school of the university, and finally for each SDG.

\subsection{Overall Results for the University of Iceland}

The number of courses listed in the University of Iceland course catalogue and analysed in this study was 3239. The total number of SDG signs evident in course descriptions and course learning outcomes was 4342 . Table 2 shows the number of courses analysed per school, the number of SDG signs found in course descriptions and learning outcomes of each course, and the average SDG signs per analysed course. The highest number of analysed courses was for the School of Humanities (770 courses), but the lowest number was for the School of Education (463 courses). The total number of signs found in course descriptions was highest in case of the School of Social Sciences (1519 signs) but was by far the lowest in the case of the School of Humanities. When calculating the average number of SDG signs per course, the highest proportion appeared in the cases of the School of Education (2.5 signs per course) and the School of Social Sciences (2.3 signs per course). The lowest average appeared in case of the School of Humanities (0.3) and the School of Engineering and Natural Sciences (0.8).

Table 2. Number of courses analysed and number of SDGs signs.

\begin{tabular}{cccc}
\hline Schools & Number of Courses & Number of SDG Signs & Average SDG Signs per Course \\
\hline SoEd & 463 & 1158 & 2.5 \\
SoEN & 689 & 560 & 0.8 \\
SoHS & 642 & 847 & 1.3 \\
SoHu & 770 & 258 & 0.3 \\
SoSS & 675 & 1519 & 2.3 \\
\hline
\end{tabular}

Figure 2 shows the overall percentage of signs of the SDGs in the University of Iceland course catalogue for the 2019-2020 school year. Signs of SDG 4 (quality education) were 
found in $42 \%$ of the courses, while signs of SDG 3 (good health and well-being) were found in $26 \%$ of the courses and signs of SDG 10 (reduced inequality) in $13 \%$ of the courses. Signs of SDG 1 (no poverty), SDG 2 (zero hunger), and SDG 6 (clean water) were found in 1\% or less of courses at the University of Iceland.

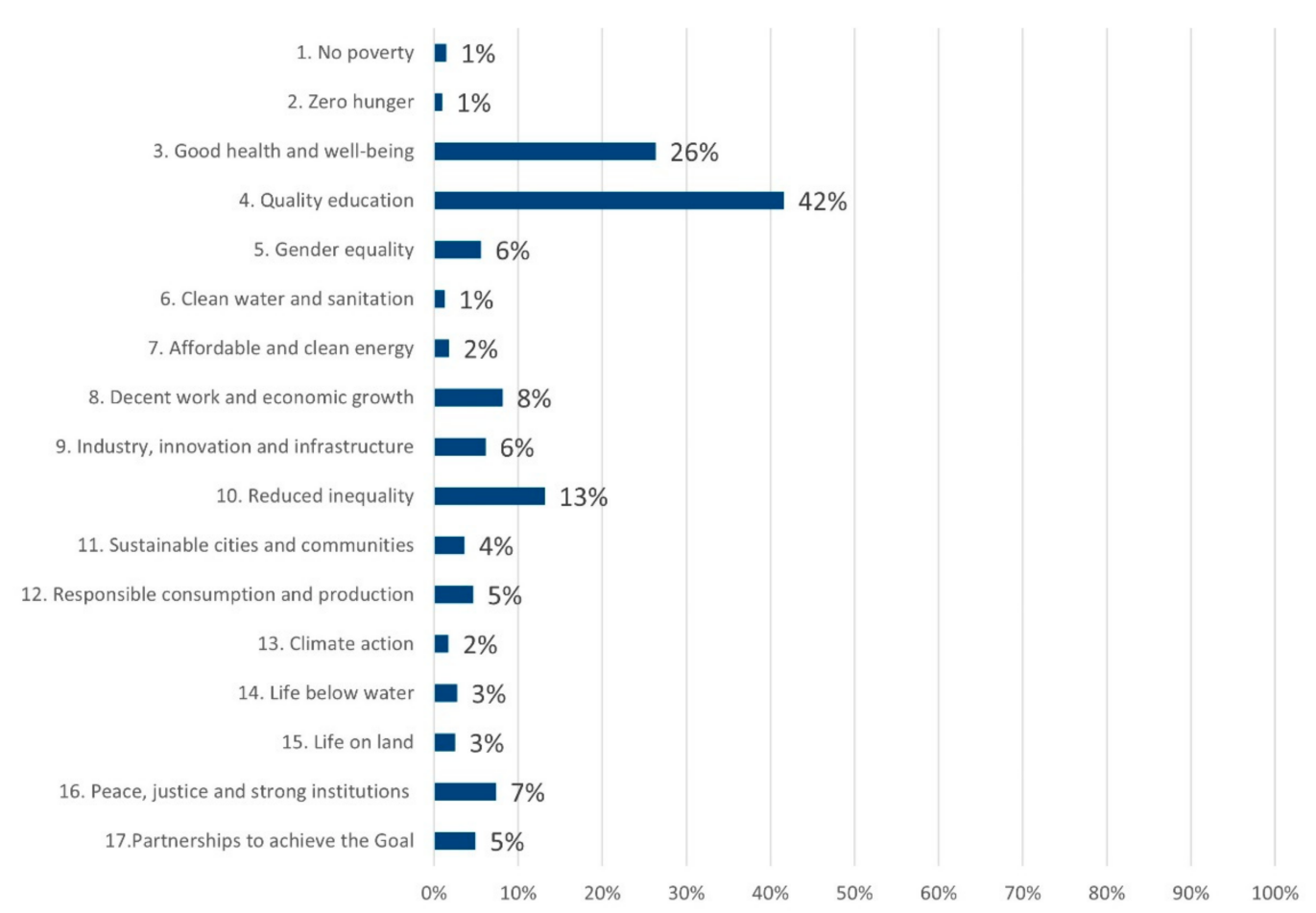

Figure 2. Overall signs (percentages) of the SDGs in the University of Iceland course catalogue.

In Figure 3, there is an overview of the ratio of SDGs signs by the number of courses by the five schools of the University of Iceland. The highest proportion of signs were found for the School of Social Sciences (green colour), the School of Education (red colour), and the School of Health Sciences (teal colour). For the School of Social Sciences (green colour), the highest proportion of signs was found for SDGs 4, 10, 16, 8, 17, and 5. For the School of Health Sciences (teal colour), their focus seemed primarily to be on SDGs 3 and 4 . The focus of the School of Education (red colour) seemed principally to focus on SDGs 4, 3, 10, and 9. In the cases of the School of Engineering and Natural Sciences and the School of Humanities, only a few signs were recorded. However, in the School of Engineering and Natural Sciences (orange colour), the most evident signs appeared for SDGs 11, 12, 9, 14, and 15. In the case of the School of Humanities (yellow colour), the main signs were of SDGs 4,10 , and 5.

\subsection{Results for Each of the Five Schools of the University of Iceland}

Figures 4-8 demonstrate the proportion of SDGs appearing for individual schools at the University of Iceland based on the number of courses analysed for each school. Figure 4 shows the outcome for the School of Education. In this case, 463 courses were analysed, with 1158 signs evident, resulting in an average of 2.5 signs per course. Given the 17 SDGs, the maximum total number of signs per course could have been 17, equal to the number of the SDGs. For the School of Education, signs of SDG 4 were found in $99 \%$ of the courses, followed by signs of SDG 3 in $46 \%$ of the courses, SDG 10 in $27 \%$ of the courses, and SDG 9 in $22 \%$ of the courses. The fewest signs of SDGs in the School of Education were found for SDGs $1,13,2$ and 7. 


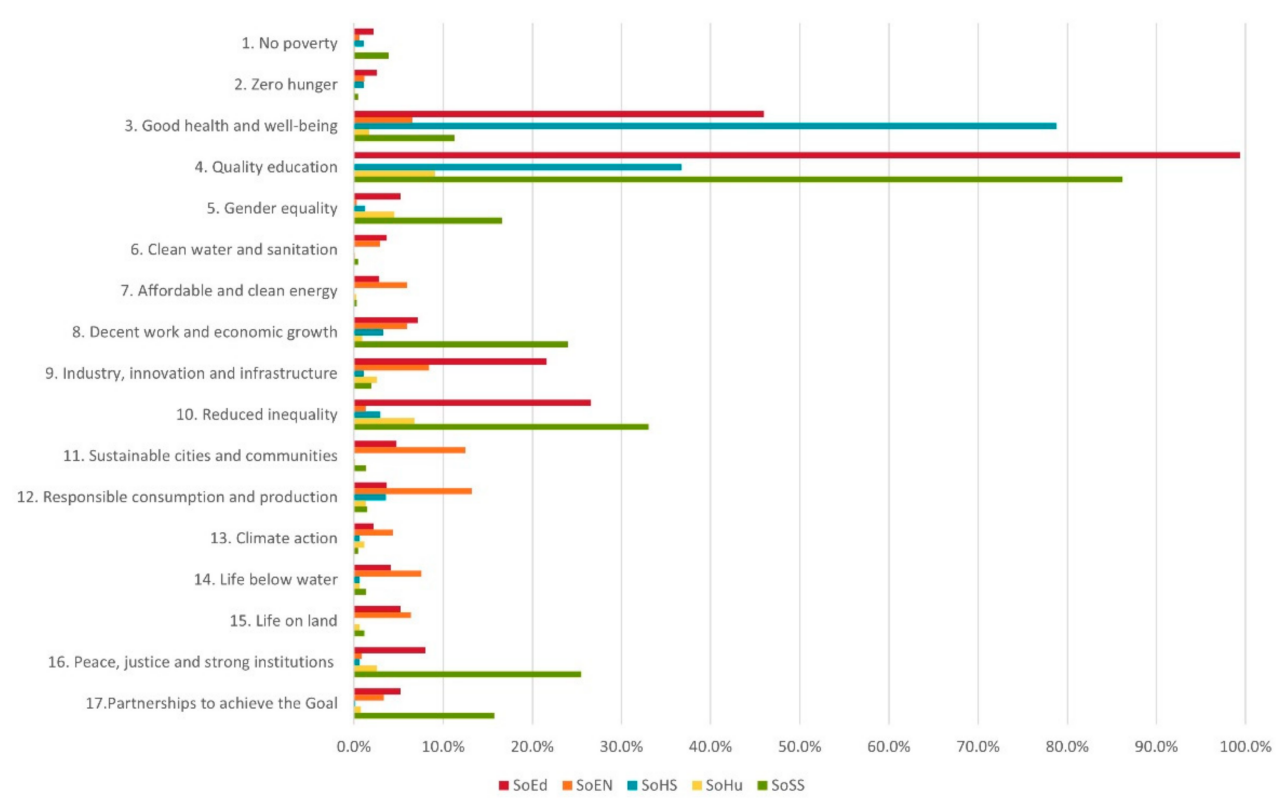

Figure 3. Clustered bar showing the proportion of SDGs signs by number of courses in the five schools of the University of Iceland.

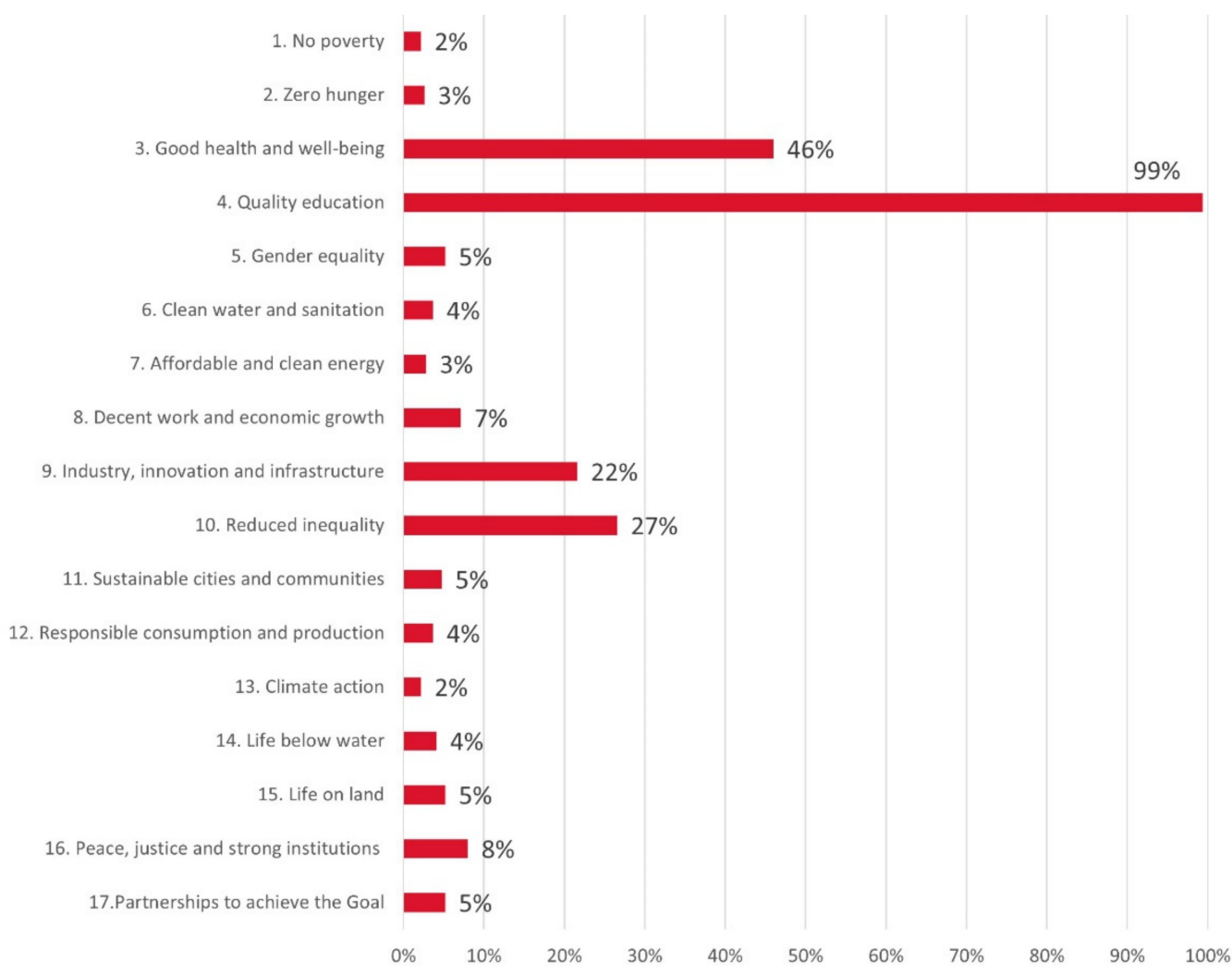

Figure 4. Percentage of signs of the SDGs found at the School of Education (SoED). 


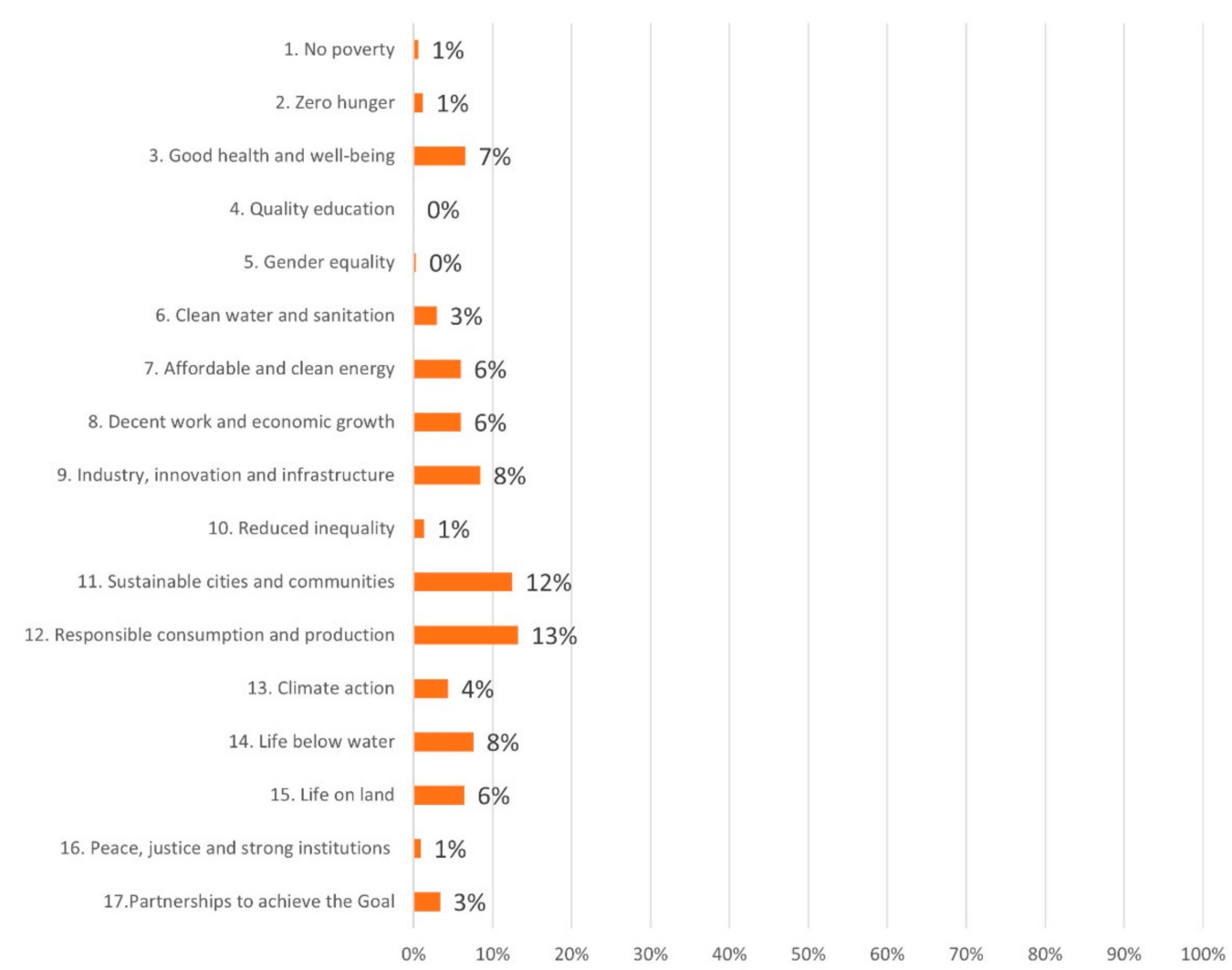

Figure 5. Percentage of signs of the SDGs at the School of Engineering and Natural Sciences (SoEN).

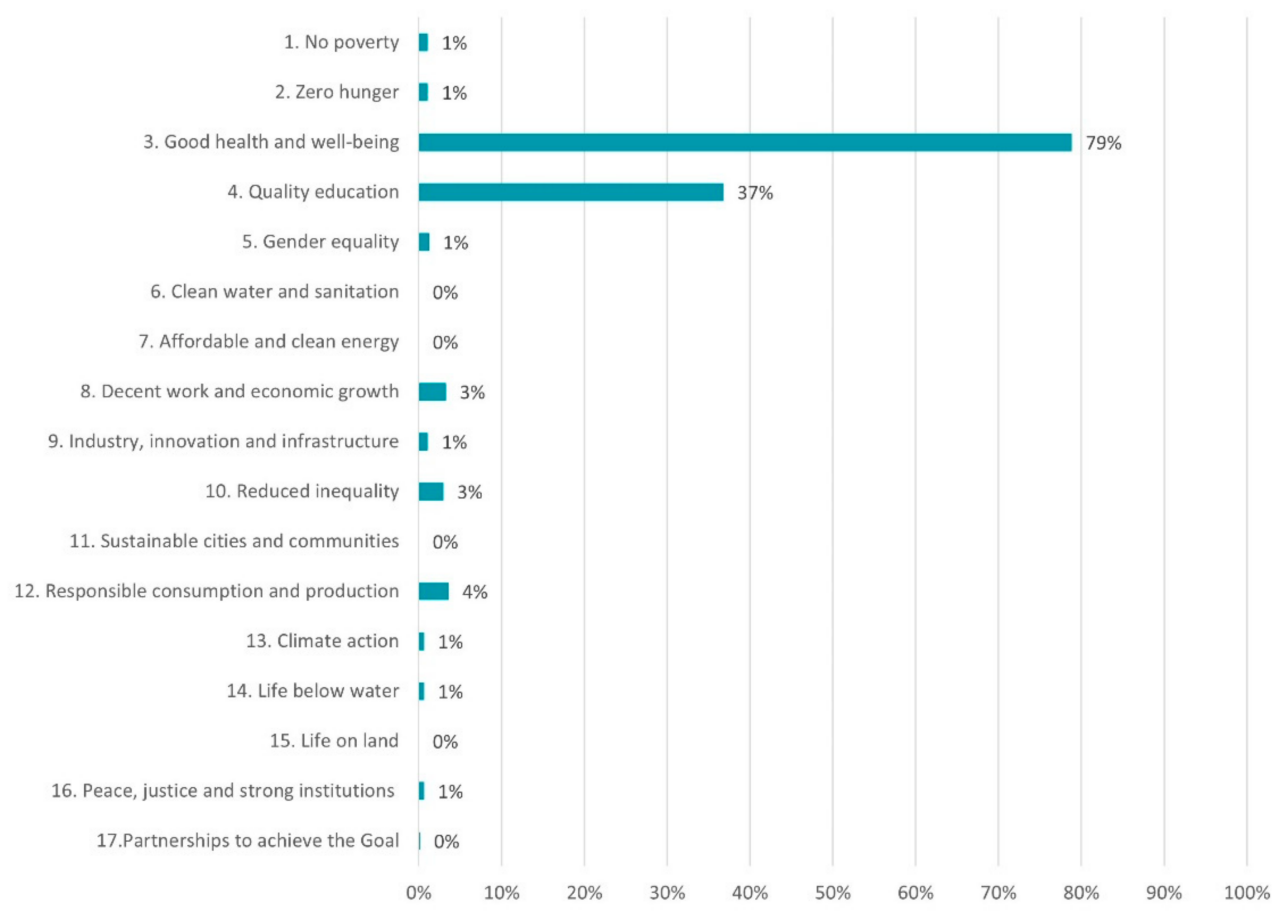

Figure 6. Percentage of signs of the SDGs at the School of Health Sciences (SoHS). 


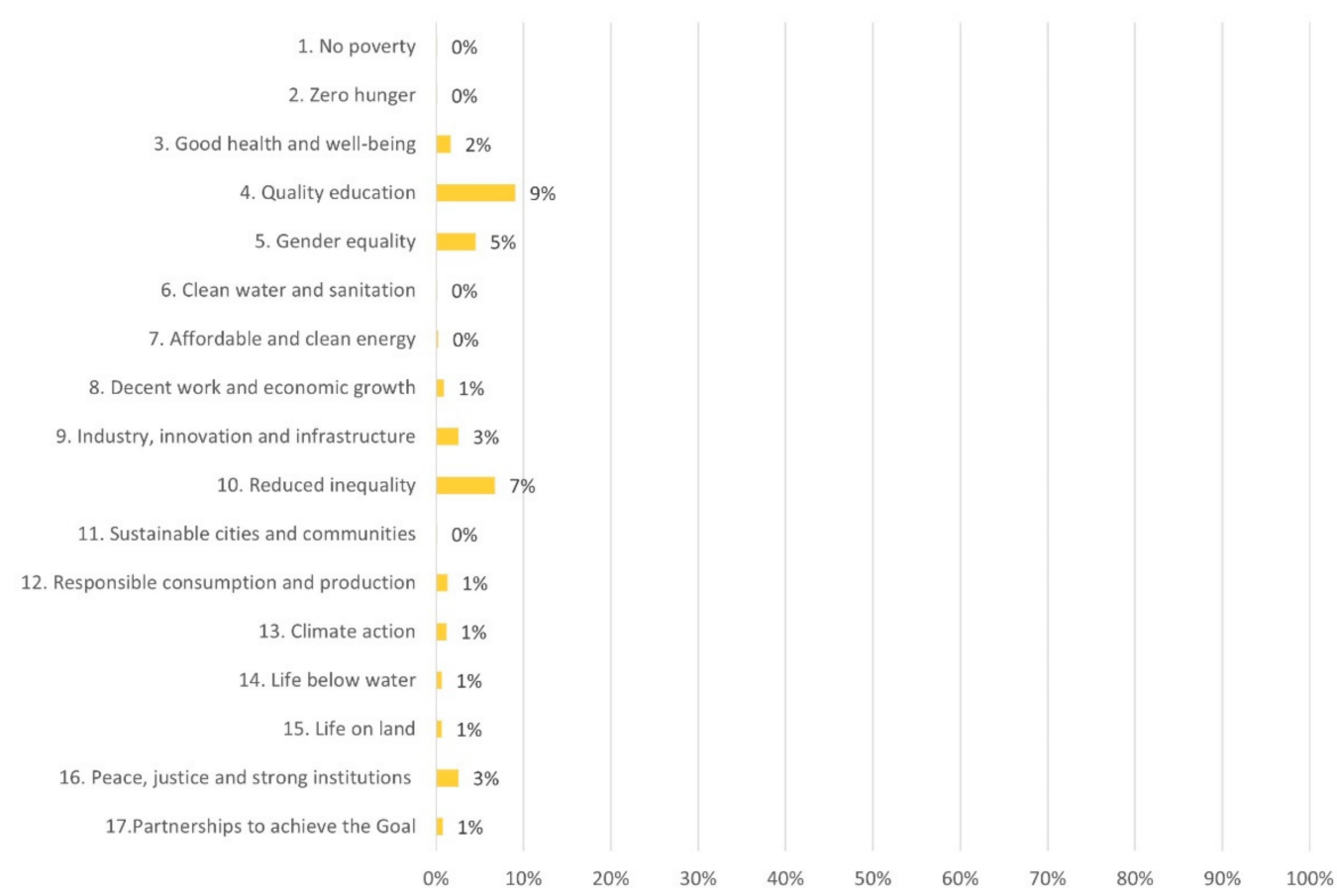

Figure 7. Percentage of signs of the SDGs at the School of Humanities (SoHu).

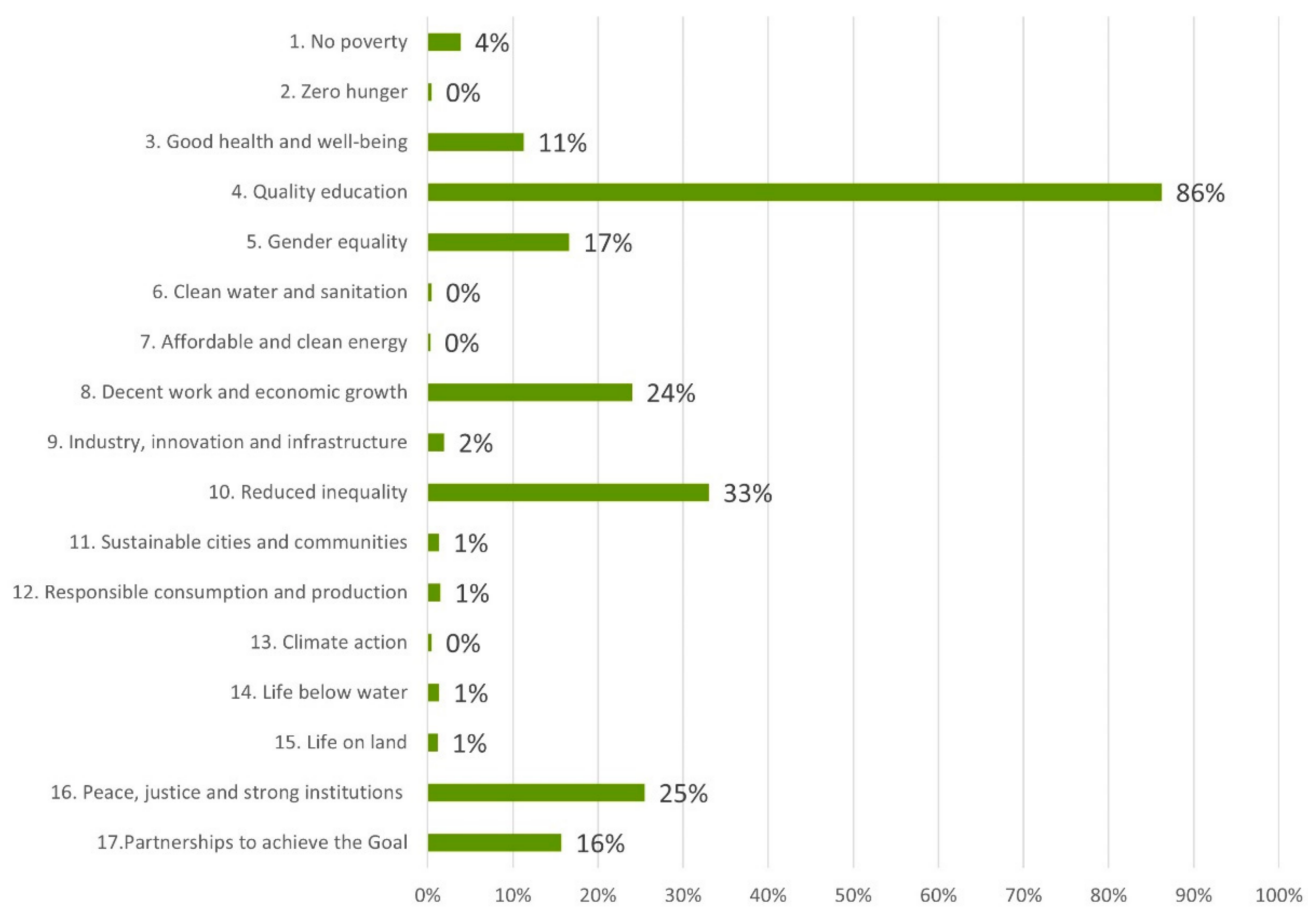

Figure 8. Percentage of signs of the SDGs at the School of Social Sciences (SoSS).

Figure 5 demonstrates the outcome for the School of Engineering and Natural Sciences. In this case, 689 courses were analysed, and the number of signs found in course descriptions and learning outcomes was 560, resulting in an average sign per course of 0.8. Proportionally, most signs were found for SDG 11 in $12 \%$ of courses and 12 in $13 \%$ of courses. Signs of four SDGs appeared in 1\% of the courses, i.e., SDGs 1, 2, 10, and 16. Signs of two SDGs appeared in less than 1\% of the courses at the School of Engineering and Natural Sciences, i.e., SDGs 4 and 5. 
Results for the School of Health Sciences are presented in Figure 6. In this case, 642 courses were analysed, and the number of SDG signs recorded was 847, resulting in an average of 1.3 signs per course. Signs of SGSs are mainly associated with two SDGs. Signs of SDG 3 were analysed in 79\% of courses in this school, and SDG 4 appeared in 37\% of the courses. Signs of seven SDGs appeared in 1\% of the courses, i.e., SDGs 1, 2, 5, 9, 13, 14, and 16. Signs of five SDGs appeared in less than $1 \%$ of the courses at the School of Health Sciences, i.e., SDGs 6, 7, 11, 15, and 17.

The highest number of courses (770 courses) analysed occurred in the School of Humanities (see Figure 7). However, the fewest number of signs were recorded in the school's courses or 258 in total, resulting in an average 0.3 signs per course. Three SDGs stand out, which are signs of SDG 4 in 9\% of courses, SDG 7 in 7\% of courses, and SDG 5 in $5 \%$ of the courses. Signs of six SDGs appeared in $1 \%$ of the courses, i.e., SDGs 8, 12, 13, 14,15 , and 17. Signs of five SDGs appeared in less than $1 \%$ of the courses at the School of Humanities, i.e., SDGs 1, 2, 6, 7, and 11.

The number of courses analysed for the School of Social Sciences was 675 courses, where 1519 signs were found, resulting in an average 2.3 signs per course (see Figure 8). Proportionally, most signs were found for SDG 4 in $86 \%$ of the courses, followed by SDG 10 in $33 \%$ of the courses, SDG 16 in $25 \%$ of the courses, and SDG 8 in $24 \%$ of the courses. Signs of four SDGs appeared in 1\% of the courses, i.e., SDGs 2, 6, 7, and 13. Signs of four SDGs appeared in less than $1 \%$ of the courses at the School of Social Sciences, i.e., SDGs 11, 12,14 , and 15.

In sum, Figures 4-8 demonstrate the proportion of SDGs appearing for individual schools at the University of Iceland based on the number of courses analysed in each school. In some cases, strong signs were evident for individual SDGs, such as signs of SDG 4 (quality education) at the School of Education and the School of Social Sciences or SDG 3 (good health and well-being) at the School of Health Sciences. In other cases, the outcome was dispersed and not so clear, i.e., in the case of the School of Engineering and Natural Sciences and the School of Humanities, showing overall the weakest signs of the SDGs in the course descriptions.

\subsection{Results by the 17 SDGs}

Having examined the results for each of the five schools at the University of Iceland, indications of each school's strength and weaknesses on the SDGs appeared. Now, the results of each SDG by the five schools of University of Iceland are presented.

First, in Figure 9, the proportion of SDGs 1, 2, 3, and 4 for each of the schools at the University of Iceland are presented. These results indicate an overall limited emphasis on SDGs 1 and 2 within the university as whole. In terms of SDG 1, there seems to be a recognisable emphasis within the School of Social Sciences (3.9\%), and in terms of SDG 2 there seems to be a recognisable emphasis within the School of Education $(2.6 \%)$. Not surprisingly, the main emphasis within the School of Health Sciences appears on SDG 3 in $78.8 \%$ of their courses, as this aspect is inherent to its role within the University. Moreover, the School of Education seems to place considerable emphasis on SDG $3(46.0 \%)$. In terms of SDG 4, the School of Education seems to include that SDG in most of its courses (99.4\%), as could be expected. Additionally, SDG 4 seems to have a strong focus in the School of Social Sciences $(86.2 \%$ of courses) and in about a third of courses $(36.8 \%)$ in the School of Health Sciences. It should be noted that the scale of the figures for SDGs 1 and 2 was $0-35 \%$, whereas, for SDGs 3 and 4 , the scale was $0-100 \%$. 

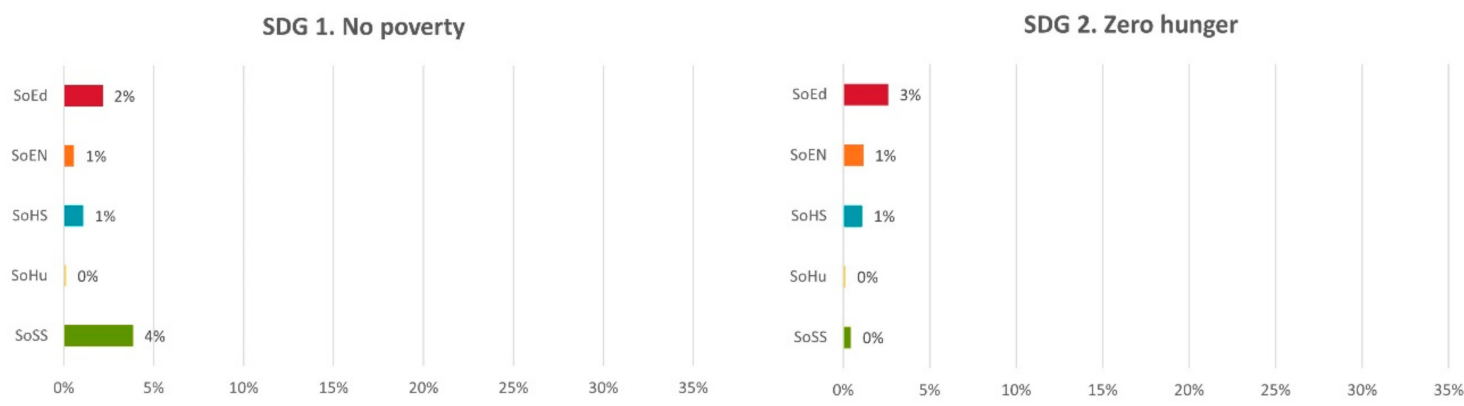

SDG 3. Good health and well-being

SDG 4. Quality education
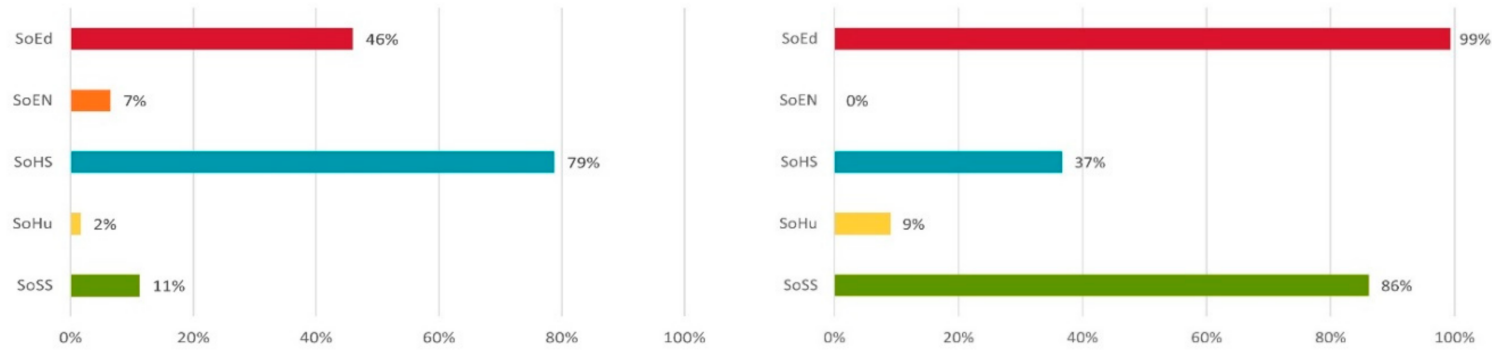

Figure 9. Proportion of signs for SDGs 1-4 by number of courses in each of the five schools at the University of Iceland.

In Figure 10 below, the outcome for SDGs 5, 6, 7, and 8 is presented. Of these, SDGs 6 and 7 seem proportionally less evident in the university's curriculum than SDGs 5 and 8. The emphasis on SDG 5 seemed most evident in the School of Social Sciences courses $(16.6 \%)$, followed by the School of Education (5.2\%). In case of SDG 6, the signs of these aspects were found in courses within the School of Education (3.7\%) and the School of Engineering and Natural Sciences (2.9\%). The School of Health Sciences and the School of Humanities seemed to place a negligible emphasis on SDG 7, which was most visible in courses at the School of Engineering and Natural Sciences (6.0\%). SDG 8 was to the greatest extent visible in courses provided by the School of Social Sciences $(24.0 \%)$.
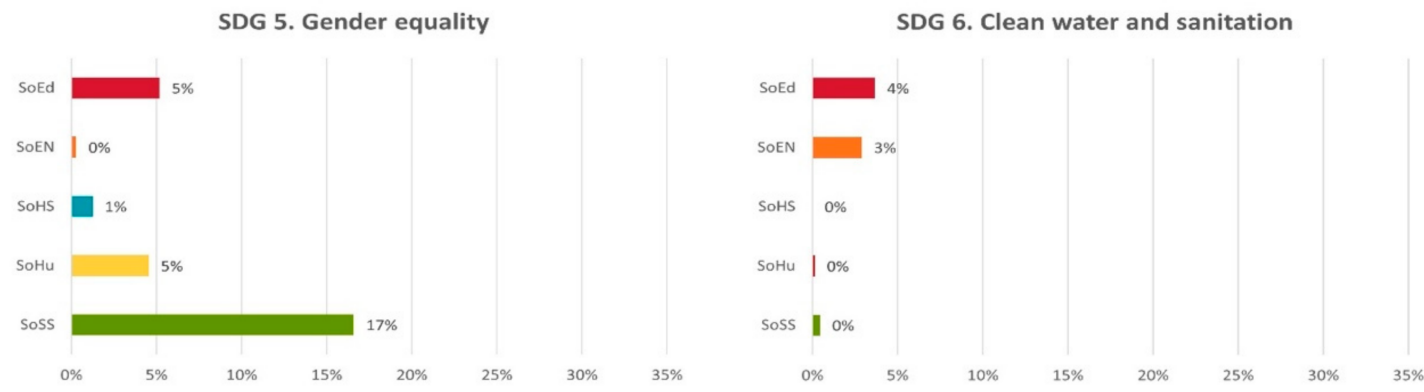

SDG 7. Affordable and clean energy

SDG 8. Decent work and economic growth
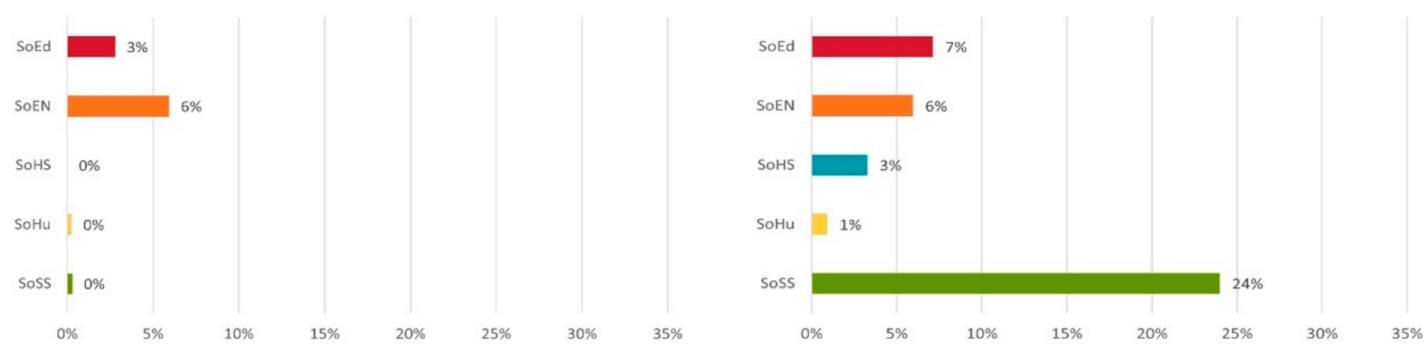

Figure 10. Proportion of signs for SDGs 5-8 by number of courses in each of the five schools at the University of Iceland. 
In Figure 11 below, the outcome for SDGs 9, 10, 11, and 12 is presented. Relatively most signs of SDG 10 were found within the School of Social Sciences $(30.0 \%)$ and the School of Education (26.6\%). On the other hand, a limited emphasis seemed to be on this aspect in courses within the School of Engineering and Natural Sciences (1.3\%). For SDG 9, the far-highest recorded emphasis appeared in courses at the School of Education (21.6\%), followed by the School of Engineering and Natural Sciences (8.4\%). Of the four SDGs presented in Figure 11, the relatively fewest signs were recorded for SDG 11. In the School of Engineering and Natural Sciences, $12.5 \%$ of their courses had signs of SDG 11, but negligible signs SDG 11 were found at the School of Health Sciences and the School of Humanities. Signs of SDG 12 appeared mainly in courses at the School of Engineering and Natural Sciences (13.2\%) but least within the School of Social Sciences (1.5\%). This finding came as a surprise since the Faculty of Business Administration and the Faculty of Economics are both headed under the SoSS.

SDG 9. Industry, innovation and infrastructure

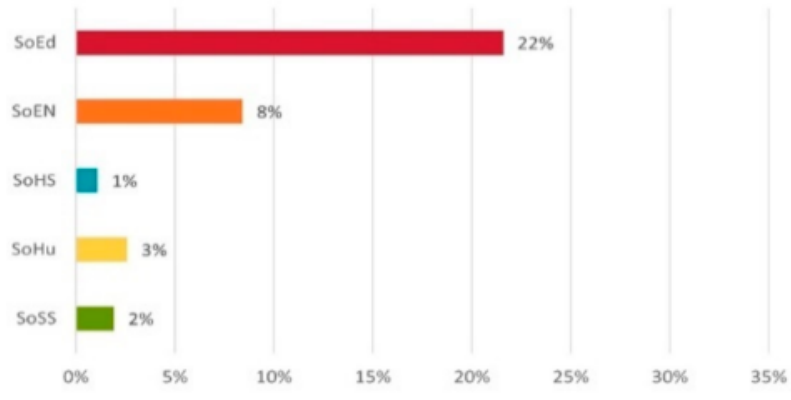

SDG 11. Sustainable cities and communities

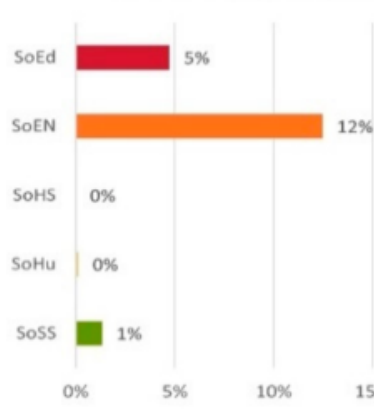

SDG 10. Reduced inequality

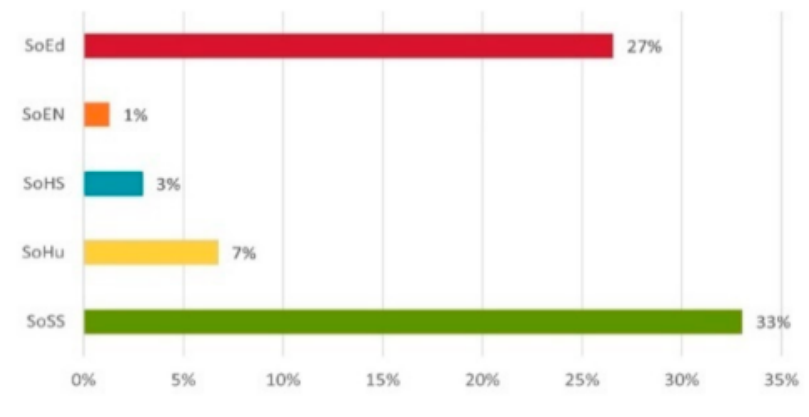

SDG 12. Responsible consumption and production

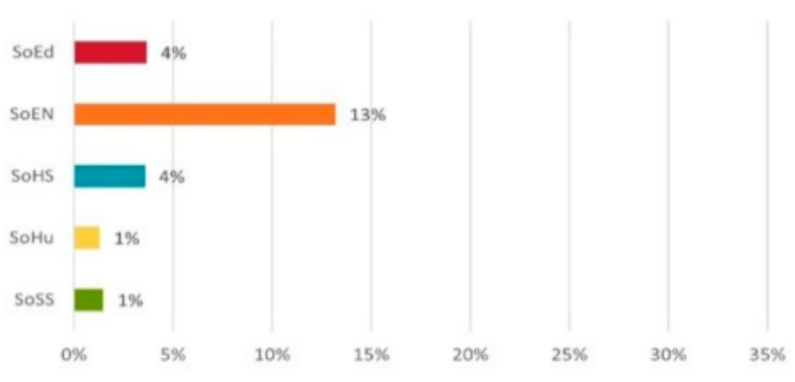

Figure 11. Proportion of signs for SDGs 9-12 by number of courses in each of the five schools at the University of Iceland.

In Figure 12 below, the outcome for SDGs 13-17 is presented. Signs of climate actions (SDG 13) were overall few, but some emphasis seemed to occur in courses at the School of Engineering and Natural Sciences (4.4\% of their courses). On SDGs 14 and 15, the most evident, but not strong, emphasis appeared in courses at the School of Engineering and Natural Sciences followed by the School of Education. For SDG 16, relatively most signs were found in courses at the School of Social Sciences (25.5\%) followed by the School of Education (8\%). For SDG 17, on partnership to achieve goals, relatively most signs were found in courses at the School of Social Sciences (15.7\%).

In sum, Figures 9-12 show the results of each SDG by the five schools of the University of Iceland. It demonstrates a strong emphasis on some of the SDGs, such as on quality education (SDG 4) and good health and well-being (SDG 3), where it should be noted that the scales were higher $(100 \%)$ than for all the other SDGs presented. However, it differed greatly between the schools on which SDGs were emphasised most. For instance, the School of Social Sciences emphasised peace, justice, and strong institutions (SDG 16) and reduced inequality (SDG 10), whereas the School of Engineering and Natural Sciences seemed to place an emphasis on responsible consumption and production (SDG 12) and 
sustainable cities and communities (SDG 11). This analysis also reveals limited emphasis on a few SDGs such as no poverty (SDG 1), zero hunger (SDG 2), clean water and sanitation (SDG 6), and climate actions (SDG 13).
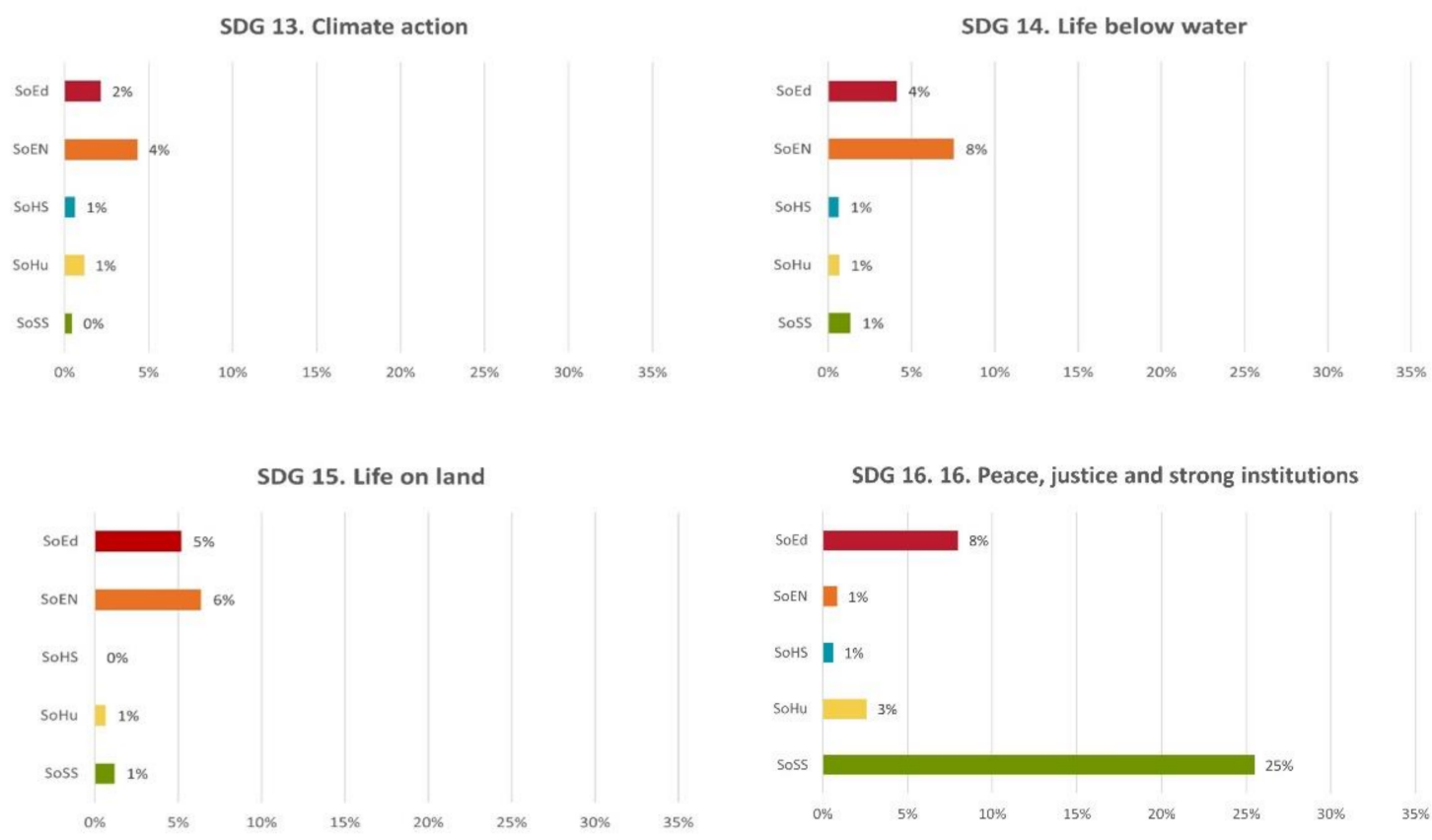

Figure 12. Proportion of signs for SDGs 13-17 by number of courses in each of the five schools at the University of Iceland.

\section{Discussion and Conclusions}

The purpose of this research was to provide an overview of the United Nations Sustainable Development Goals (SDGs) in the curriculum of the five schools at the University of Iceland and an overview of individual SDGs for the university, to identify the main challenges and opportunities for improvement [4,5]. The nature of education is to be in constant development where content and approaches are under scrutiny. However, the results of this research indicate that there is ample space for improvement within the courses of the University of Iceland. The most obvious opportunities include revision of the course descriptions and learning outcomes, with the SDGs in mind, to make what is already being focused on more explicit.

From the standpoint of the SDGs put forward by the UN in 2015 [4,5] and the high ranking of disciplines in the School of Engineering and Natural Sciences for the year 2021 [28], it was a surprise to find how low the proportion of SDGs, e.g., 14, 15, 6, 7, 13, and 17, appeared for that school. For the School of Social Sciences, the authors expected a higher proportion of signs for SDGs 1,2,12, 16 and 17, but signs of these SDGs were found in $5 \%$ or less within the University of Iceland.

Comparing recent research at the University of Helsinki [20] and the results of this study, some differences appeared. In the Finnish analysis, data included information 
about course offerings and university policy documents, like this research, but, in addition, the Finnish research included data on publish research and grant applications. Based on analysis of course offerings, the Finnish research reported clear signs of SDG 3 (good health and well-being) but almost no emphasis on SDG 1 (no poverty), like the results of this research. However, unlike the results of this research, the Finish results indicated a clear emphasis on SDG 17 (partnership for the goals). Nowhere in the Finish data appeared signs of SDG 5 (gender equality), which in this research was found in $6 \%$ of courses in the University of Iceland.

The International University of Catalonia aimed to explore the principles linked between the SDGs and the learning and teaching practices in sustainability [21]. Their results were like the results of this research indicating little focus on climate change, regional development, actions on poverty, or corporate social responsibility.

When examining these results for the University of Iceland at this timepoint, the question of usefulness of such a study is raised. In the aforementioned guidelines, made under the auspices of the UN on the implementation of the SDGs in the policy and practice of universities, five steps organised in three phases were introduced [10]. The first phase includes mapping what is already done and by whom, e.g., in terms of the content of courses and offered programmes. This research is a large step within the first phase and is part of the second one since indications of main challenges and opportunities for improvement have been identified. The next steps need to include building a capacity and ownership of the SDGs in line with the university's newly issued policy for 2021-2026. Then, integration of the SDGs into practice will call for monitoring, evaluation, and communication of progress, which are the core of the third phase of the model defined for effectively creating policy and practices of universities [26]. Here, the recent research of implementing sustainability competencies will be of particular help and serve as guidance [15]. The main contribution of this research was an example of how a university can acquire an overview of its current situation of the curriculum, being a part of an official policy of each university. As explained, this overview can be the first step in recognising what is already in place in the implementation process within each university, both on the level of comparing academic units (as the schools of University of Iceland) and the level of each SDG.

The implications of these results bring forward the need for each school of the university to scrutinise their own course offerings asking if and how they could make topics related to the SDGs more explicit in course descriptions and learning outcomes. In the preparation phase and during the pilot and execution phases of this research there appeared clear indications of urgent revision of course descriptions and learning outcomes in all the five schools for securing required information about each course. Moreover, in the pilot phase there were examples revealed about courses where the information in the course catalogue (the description text and learning outcomes) were not in line with the actual practice of the course.

These results could be used as a foundation for organising courses and programmes for students to select by the SDGs. This seems to be growing practice within universities, such as in the case of Aalto University in Finland, which "has signed an international Sustainable Development Goals (SDG) Accord," thereby committing itself to advance the SDGs "as part of its teaching, research, innovation activities, and campus development" [39]. Additionally, the University of Duisburg-Essen has stressed how the university undertakes action on sustainability, aligned with the SDGs, in various fields of its operation, namely, in research, teaching, and daily operations [14]. Finally, these results can be of use for coordinators of individual courses within the University of Iceland, asking what and how their courses do relate to the SDGs and how the courses could be adjusted to be more in line with the emphasis put forward by the UN.

There is no doubt that ahead is a lot of work within the University of Iceland, which is quite complex in many respects. Considering the results of the research from Harvard University [23], the key to successful implementation of the SDGs into the practice and policy of a university is based on how determined the authorities of the university are. 
Here, it seems most important to make the SDGs as a foundational frame for policy and practice of the university and to participate in extensive international collaboration on the SDGs since such projects work as a collective power for the implementation [23]. In this respect, the University of Iceland seems to be on right track since it is a leading participant in the Aurora network of European universities with a strong focus on sustainability and the SDGs [40,41].

However, as in other research, there are limitations. In data collection, each course could only obtain the value 1 for each SDG, regardless of the number of signs appearing. Moreover, each course had the same weight in the analysis regardless of the size of the course (mainly being 4-10 ECTS). These factors could influence the results. However, the aim of this research, which is the first one in Iceland according to our knowledge, was to provide a collective overview for the SDGs for individual schools for the university and to obtain a university overview of individual SDGs, to know the main challenges and opportunities for improvement.

In sum, the results of this research indicate ample opportunities for the University of Iceland in relation to the UN SDGs. However, the university seems to be following similar footsteps as other universities walk the path of implementing the SDGs into policy and practice. The results of this research can also serve as a benchmark for other universities, e.g., for comparison of results and the model used for effectively creating policy and practices of universities.

Author Contributions: Conceptualization A.P. and L.J.; methodology A.P. and L.J.; validation, A.P. and L.J.; formal analysis and data curation, A.P. and L.J.; writing-original draft preparation, review and editing, A.P. and L.J.; supervision, A.P. and L.J.; project administration, A.P. and L.J. All authors have read and agreed to the published version of the manuscript.

Funding: This research received no external funding.

Institutional Review Board Statement: Not applicable.

Informed Consent Statement: Not applicable.

Data Availability Statement: The analytical framework is available from the corresponding author upon request.

Acknowledgments: The authors would like to thank Hildur Hallkelsdóttir [42] who analysed courses at the School of Education, Atli Rafnsson [43] who analysed the courses of the School of Engineering and Natural Sciences, Guðjón Már Sveinsson [44] who analysed courses at the School of Health Sciences, Bjarni Bachmann [45] who analysed courses at the School of Humanities, and Hafdís Ósk Jónsdóttir [46] who analysed courses at the School of Social Sciences, all at the University of Iceland.

Conflicts of Interest: The authors declare no conflict of interest.

\section{References}

1. IPCC [The Intergovernmental Panel on Climate Change]. Global Warming of $1.5^{\circ} \mathrm{C}$. An IPCC Special Report on the Impacts of Global Warming of $1.5^{\circ} \mathrm{C}$ Above Pre-Industrial Levels and Related Global Greenhouse Gas Emission Pathways, in the Context of Strengthening the Global Response to the Threat of Climate Change, Sustainable Development, and Efforts to Eradicate Poverty; World Meteorological Organisation: Geneva, Switzerland, 2018; p. 32.

2. Sterling, S. Planetary Primacy and the Necessity of Positive Dis-Illusion. Sustainability 2019, 12, 60-66. [CrossRef]

3. Stough, T.; Ceulemans, K.; Lambrechts, W.; Cappuyns, V. Assessing sustainability in higher education curricula: A critical reflection on validity issues. J. Clean. Prod. 2017, 172, 4456-4466. [CrossRef]

4. Heimsmarkmiðin um Sjálfbæra Próun. Heimsmarkmiðin. Available online: https://www.heimsmarkmidin.is/forsida/ heimsmarkmidin/ (accessed on 21 June 2021).

5. United Nations. The 17 Goals. Available online: https://sdgs.un.org/goals (accessed on 18 June 2021).

6. United Nations. Transforming our World: The 2030 Agenda for Sustainable Development. Available online: https://sdgs.un.org/ 2030agenda (accessed on 18 June 2021).

7. European Environment Agency. The European Environment-State and Outlook 2020. Executive Summary; Publications Office of the European Union: Luxembourg, 2019; pp. 1-12.

8. Conceição, P. The 2020 Human Development Report; United Nations Development Programme: New York, NY, USA, 2020. 
9. Leal Filho, W.; Wu, Y.-C.J.; Brandlid, L.L.; Avilae, L.V.; Azeiteirof, U.M.; Caeirog, S.; Madrugah, L.R. Identifying and overcoming obstacles to the implementation of sustainable development at universities. J. Integr. Environ. Sci. 2017, 14, 93-108. [CrossRef]

10. SDSN [Sustainable Development Solutions Network] Northern Europe. New Guide on Accelerating Education for the SDGs in Universities; Sustainable Development Solutions Network: New York, NY, USA, 2020.

11. Johannsdottir, L.; Cook, D. Systemic risk of maritime-related oil spills viewed from an Arctic and insurance perspective. Ocean. Coast. Manag. 2019, 79, 1-17. [CrossRef]

12. Institute of Medicine. The role of universities. In Trends in the Innovation Ecosystem: Can Past Successes Help Inform Future Strategies? Summary of Two Workshops; The National Academies Press: Washington, DC, USA, 2013; pp. 17-24.

13. Parliament of Iceland. Law on Universities, no 63/2006. Available online: https://www.althingi.is/lagas/nuna/2006063.html (accessed on 5 July 2021).

14. University of Duisburg-Essen. Sustainable Development at the University of Duisburg-Essen; University of Duisburg-Essen: Essen, Germany, 2020.

15. Lozano, R.; Barreiro-Gen, M. Developing Sustainability Competences through Pedagogical Approaches. Experiences from International Case Studies; Springer: Cham, Switzerland, 2021; p. 342.

16. Leal Filho, W.; Wall, T.; Salvia, A.L.; Frankenberger, F.; Hindley, A.; Mifsud, M.; Brandli, L.; Will, M. Trends in scientific publishing on sustainability in higher education. J. Clean. Prod. 2021, 296, 126569. [CrossRef]

17. Leal Filho, W.; Shiel, C.; Paço, A.; Mifsud, M.; Ávila, L.V.; Brandli, L.L.; Molthan-Hill, P.; Pace, P.; Azeiteiro, U.M.; Vargas, V.R.; et al. Sustainable Development Goals and sustainability teaching at universities: Falling behind or getting ahead of the pack? J. Clean. Prod. 2019, 232, 285-294. [CrossRef]

18. SDSN [Sustainable Development Solutions Network]. Getting Started with the Sdgs in Universities: A Guide for Universities-Higher Education Institutions and the Academic Sector; SDSN: New York, NY, USA, 2017.

19. SDSN [Sustainable Development Solutions Network]. Accelerating Education for the Sdgs in Universities: A Guide for Universities, Colleges, and Tertiary and Higher Education Institutions; SDSN: New York, NY, USA, 2020.

20. Korhonen-Kurki, K.; Koivuranta, R.; Kuitto, V.; Pietikainen, J.; Schonach, R.; Soini, K. Towards Realising SDGs in the University of Helsinki. In Sustainable Development Goals and Institutions of Higher Education; Nhamo, G., Mjimba, V., Eds.; Sustainable Development Goals Series; Springer: Cham, Switzerland, 2020; pp. 15-29.

21. Albareda-Tiana, S.; Vidal-Raméntol, S.; Fernández-Morilla, M. Implementing the sustainable development goals at University level. Int. J. Sustain. High. Educ. 2018, 19, 473-497. [CrossRef]

22. Solís-Espallargas, C.; Ruiz-Morales, J.; Limón-Domínguez, D.; Valderrama-Hernández, R. Sustainability in the University: A Study of Its Presence in Curricula, Teachers and Students of Education. Sustainability 2019, 11, 6620. [CrossRef]

23. Purcell, W.M.; Henriksen, H.; Spengler, J.D. Universities as the engine of transformational sustainability toward delivering the sustainable development goals. "Living labs" for sustainability. Int. J. Sustain. High. Educ. 2019, 20, 1343-1357. [CrossRef]

24. Paletta, A.; Fochi, P.; Toschi, T.G.; Ubertini, F. Adoption of the SDGs as a Reporting Framework at the Alma Mater Studiorum (University of Bologna) in Italy. In Sustainable Development Goals and Institutions of Higher Education; Nhamo, G., Mjimba, V., Eds.; Sustainable Development Goals Series; Springer: Cham, Switherland, 2020; pp. 185-197.

25. Lozano, R.; Barreiro-Gen, M.; Lozano, F.J.; Sammalisto, K. Teaching sustainability in Higher Education Institutions: Assessing the Connections between competences and pedagogical approaches. Sustainability 2019, 11, 1602. [CrossRef]

26. University of Iceland. The University. Available online: https://english.hi.is/university/the_university (accessed on 18 June 2021).

27. The World University Ranking. University of Iceland. Available online: https://www.timeshighereducation.com/worlduniversity-rankings/university-iceland (accessed on 18 June 2021).

28. University of Iceland. Háskóli Íslands á Lista Shanghai Ranking fimm ár í röð. Available online: https://www.hi.is/frettir/ haskoli_islands_a_lista_shanghai_ranking_fimm_ar_i_rod (accessed on 18 June 2021).

29. Stofnun Árna Magnússonar í Íslenskum Fræðum. Culture. Available online: https://www.arnastofnun.is/en/front-page (accessed on 18 June 2021).

30. University of Iceland. Lykiltölur_Facts and Figures; University of Iceland: Reykjavík, Island, 2020; pp. 1-76.

31. University of Iceland. Strategic Plan of the University of Iceland 2011-2016. Available online: http:/ / aldarafmaeli.hi.is / files / policy_2011-2016.pdf (accessed on 18 June 2021).

32. University of Iceland. Strategy of the University of Iceland 2016-2021. Available online: https://english.hi.is/university/ strategy_of_the_university_of_iceland_2016_2021 (accessed on 18 June 2021).

33. University of Iceland. Betri Háskóli Betra Samfélag-Stefna 2021-2026. Available online: https://stefna.hi.is/\#Betri-haskoli (accessed on 22 June 2021).

34. University of Iceland. Course Catalogue 2019-2020. Available online: https://ugla.hi.is/kennsluskra/index.php?tab=skoli\& chapter=content\&id=-2019\&kennsluar=2019 (accessed on 18 June 2021).

35. United Nations. Goals. 1 End Poverty in All Its Forms Everywhere. Available online: https://sdgs.un.org/goals/goal1 (accessed on 5 July 2021).

36. United Nations. Goal 1: End Poverty in All Its Forms Everywhere. Available online: https://www.un.org/sustainabledevelopment/ poverty/ (accessed on 18 June 2021). 
37. Whittemore, R.; Chase, S.K.; Mandle, C.L. Validity in Qualitative Research. Qual. Health Res. 2001, 11, 522-537. [CrossRef] [PubMed]

38. Creswell, J.W. Qualitative Inquiry and Research Design: Choosing Among Five Approaches, 2nd ed.; Sage Publications, Inc.: Thousand Oaks, CA, USA, 2007.

39. Aalto University. SDGs at Aalto University. Available online: https://www.aalto.fi/en/sustainability/sdgs-at-aalto-university (accessed on 26 June 2021).

40. University of Iceland. Aurora. Available online: https:/ /english.hi.is/university/aurora (accessed on 26 June 2021).

41. Aurora European University Alliance. Aurora Universities Network. Available online: https://aurora-network.global/ (accessed on 26 June 2021).

42. Hallkelsdóttir, H. The UN Sustainable Development Goals in the University of Iceland's Course Catalogue for School of Education Academic Year 2019-2020: Assessment in each of the University's Schools. Master's Thesis, University of Iceland, Reykjavik, Island, 2020.

43. Rafnsson, A. The UN Sustainable Development Goals in the University of Iceland's Course Catalogue for the School of Engineering and Natural Sciences the Academic Year 2019-2020. Master's Thesis, University of Iceland, Reykjavik, Island, 2020.

44. Sveinsson, G.M. The UN Sustainable Development Goals in the University of Iceland's Course Catalogue for School of Health Sciences Academic year 2019-2020. Master's Thesis, University of Iceland, Reykjavik, Island, 2020.

45. Bachmann, B. The UN Sustainable Development Goals in the University of Iceland's Course Catalogue for School of Humanties Academic Year 2019-2020: The UN SDGs Key Competencies. Master's Thesis, University of Iceland, Reykjavik, Island, 2020.

46. Jónsdóttir, H.Ó. The UN Sustainable Development Goals in the University of Iceland's Course Catalogue for the School of Social Sciences for the Academic year 2019-2020: Signs of global Awareness in the Schools of the University. Master's Thesis, University of Iceland, Reykjavik, Island, 2020. 